\title{
Retro virology a macro impact in the society
}

\author{
Phillip Nhlanhla \\ From Frontiers of Retrovirology 2011 \\ Amsterdam, The Netherlands. 3-5 October 2011
}

\section{Background}

Retrovirology has been widely understood from the biomedical sciences discipline and yet it has got a huge impact in our society. The is a link between the biomedical sciences and the social sciences when coming to the issues of HIV and AIDS which has got both the elements of biomedical science in this regard looking at the retro virology and the social aspects it HIV and AIDS affects everybody and as a results the socio-economic factors of any society in that way a macro impact. The understanding of both the social context and the biomedical context need to be fused together and teach the society to be able to reduce the impact to a smaller scale.

This paper will critically debate the gap between the biomedical sciences and the social science in order to address the huge impact HIV and AIDS has caused within African context. Key results will be drawn from a comprehensive literature review from books and journal articles.

Furthermore, the paper will draw upon some lessons learned and strategic challenges in addressing biomedical and social sciences within the context of HIV and AIDS to make some recommendations and providing guidelines.

Submit your next manuscript to BioMed Central and take full advantage of:

- Convenient online submission

- Thorough peer review

- No space constraints or color figure charges

- Immediate publication on acceptance

- Inclusion in PubMed, CAS, Scopus and Google Scholar

- Research which is freely available for redistribution 